\title{
Mitochondrial Retrograde Signalling and Metabolic Alterations in the Tumour Microenvironment
}

\author{
Dongki Yang ${ }^{1}$ and Jaehong Kim ${ }^{2,3, * \mathbb{D}}$ \\ 1 Department of Physiology, College of Medicine, Gachon University, Incheon 21999, Korea; \\ dkyang@gachon.ac.kr \\ 2 Department of Biochemistry, College of Medicine, Gachon University, Incheon 21999, Korea \\ 3 Department of Health Sciences and Technology, Gachon Advanced Institute for Health Science and \\ Technology, Gachon University, Incheon 21999, Korea \\ * Correspondence: geretics@gachon.ac.kr; Tel.: +82-32-899-6441
}

Received: 27 February 2019; Accepted: 19 March 2019; Published: 22 March 2019

\begin{abstract}
This review explores the molecular mechanisms that may be responsible for mitochondrial retrograde signalling related metabolic reprogramming in cancer and host cells in the tumour microenvironment and provides a summary of recent updates with regard to the functional modulation of diverse cells in the tumour microenvironment.
\end{abstract}

Keywords: mitochondria; retrograde signalling; metabolic reprogramming; tumour microenvironment; EMT

\section{Introduction}

The precise role of the mitochondria in the pathogenesis of specific chronic diseases such as diabetes, neurodegenerative diseases and cancer is still uncertain. Advances in molecular biology and in the field of metabolic research have shown that the metabolic alterations in cancer not only are a simple secondary effect from the aberrant signalling regulation for growth and proliferation but can also act as a primary cause for tumorigenic [1], metastatic [2] and stem cell-like characteristics [3] and can cause therapeutic resistance in cancer [4]. For ATP production, healthy cells commonly use glycolysis in the absence of oxygen and OXPHOS in the presence of oxygen [5]. Despite enhanced aerobic glycolysis (Warburg effect), most cancer cells also maintain mitochondrial respiratory capacity to produce a significant amount of ATP [6-8] and functionally competent mitochondria are essential for the survival of cancer cells [9-11]. Although cancer cells in general may maintain OXPHOS function, it does not necessarily mean that cancer cells have no defects in mitochondrial respiration. Enhanced glycolysis in certain cancers is clearly due to a functional abnormality of the mitochondria $[12,13]$ from decreased expression of oxidative enzymes and transporters, a truncated TCA cycle, a lowering in the number of mitochondria and defective respiratory chain, a higher sensitivity of mtDNA to oxidative stress such as ROS injury and an increase in natural inhibitors of the mitochondrial ATP synthase $[14,15]$. Indeed, certain mtDNA mutations compromise ETC functions and result in a shift to aerobic glycolysis, a metabolic phenotype typical for cancer progression. However, dominant OXPHOS, rather than aerobic glycolysis or mixed phenotypes, can also be commonly observed in various types of cancers and is known to be responsible for the metastatic progression of cancer [2,16]. These findings indicate that cancers maintain functional mitochondria, rather than 'the defective mitochondria' that Otto Warburg's colleagues hypothesized and that metabolic flexibility is common in the progression of cancer [2]. The basic components of mitochondrial function, genetics and epigenomic regulation are discussed in detail here [17]. 
Although cancer research has focused exclusively on cancer cells, the role of stromal and immune cells in cancer progression has become a new centre of focus. Non-transformed stromal, endothelial and immune cells outnumber their neoplastic counterparts in cancer [18,19]. From early carcinogenesis to progression and metastasis, cancer cells interact with various types of stromal cells such as cancer-associated fibroblasts (CAFs), endothelial cells and immune cells in the tumour microenvironment (TME). Indeed, pleiotropic interactions between various cells are responsible for the maintenance and disturbance of homeostasis in the TME [20]. Cancer-associated metabolic changes, including metabolic flexibility, are not a strictly uniform feature of malignant cells. They also differ across distinct cancers and are found even in non-transformed cells in the TME [21,22], indicating that metabolic flexibility can occur not only from genetic changes in genomic nDNA of cancer cells but also from modulation of metabolism by cells in the TME depending on the requirements of these cells to adapt. Since rapid cell proliferation requires accelerated production of the basic cellular building blocks for assembling new cells, differences in metabolism between cancer cells and non-transformed stromal and endothelial cells together can fuel cancer growth by lactate shuttling, maximally producing substrates for biosynthesis [23-25]. However, the mechanism responsible for the pleiotropic metabolic flexibility observed in various cells in the TME remains unclear. It has been speculated that mitochondria retrograde signalling can be responsible for the metabolic flexibility and progression of cancer [26-28].

The significance of mitochondria in the regulation of metabolism is reflected by their involvement in multiple signalling pathways. Altered energy metabolism with a diverse range of metabolic profiles is commonly observed in cancer cells [26], involving genetic alterations not only in nDNA but also in mtDNA and changes in mtDNA copy number, a phenotype recently speculated to originate from the 'mitochondria to nucleus crosstalk.' Mitochondrial retrograde signalling is a major form of mitochondria to nucleus crosstalk, which enables extensive communication between the mitochondria and the nucleus, influencing many cellular and cancer phenotypes including changes in metabolism, stemness, survival, drug resistance and metastasis. Mitochondrial retrograde response in response to environmental clues was discovered in S. cerevisiae [29], a direct mitochondrial retrograde response pathway was first described in response to mtDNA depletion in S. cerevisiae [30] and elegant studies established that the retrograde signalling is conserved in yeast and mammals [31-34]. In yeast, Rtg1p and Rtg3p are transcription factors, forming a dimer that translocates from the cytosol to the nucleus to regulate gene expression, while Rtg2 $p$ functions as a sensor of mitochondrial stress (Figure 1) [35]. Although mammalian orthologs of these proteins have not been found [36], similar signalling pathways, to be discussed in the next section, definitely function in mammals.

This review explores the molecular mechanisms responsible for metabolic reprogramming related to mitochondrial retrograde signalling and provides a summary of recent updates regarding the functional modulation of cancer and host cells in the TME by mitochondrial retrograde signalling. 
A.

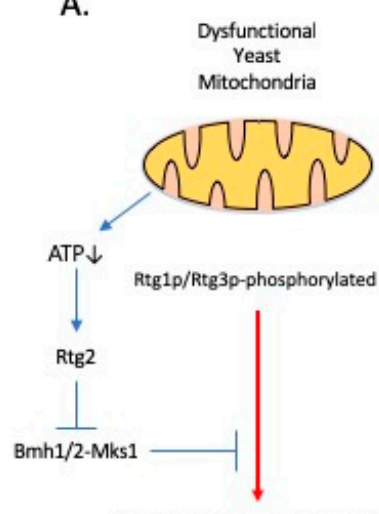

Rtg1p/Rtg3p dephosphorylated

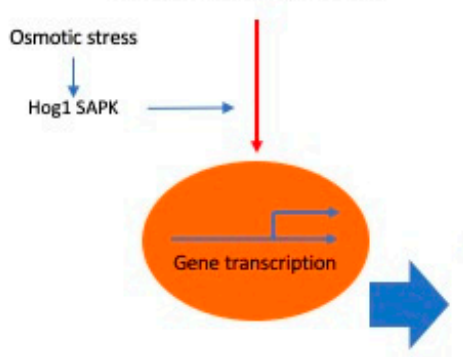

B.

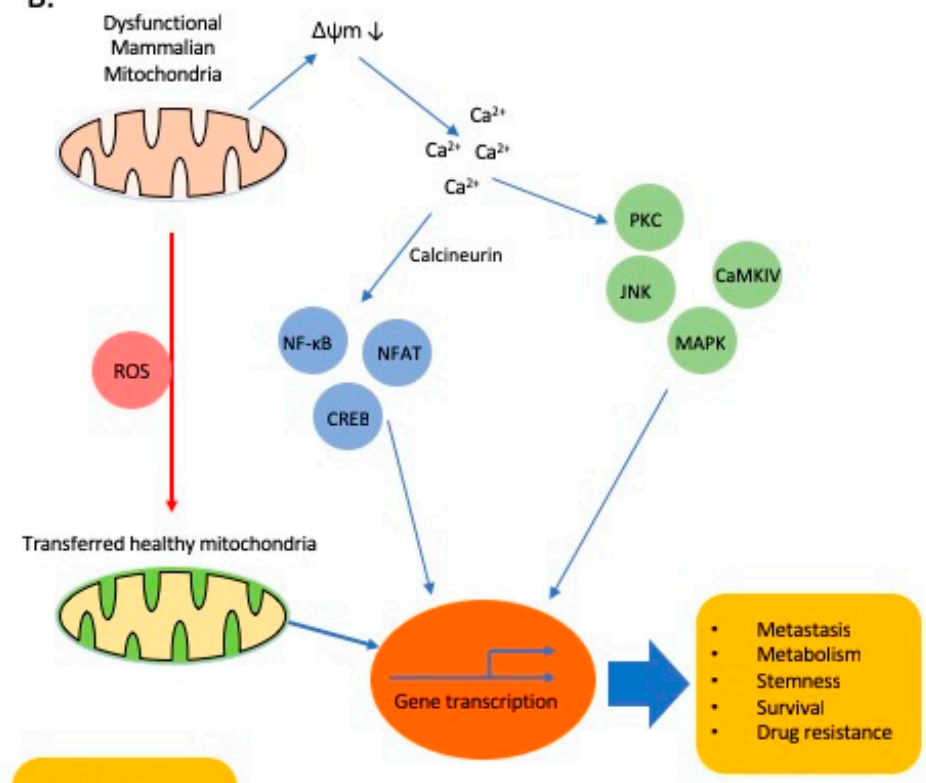

Metabolism

Osmotic stress

resistance

Mitochondria

proteostasis

Figure 1. Retrograde signalling and cellular adaptations. (A). In yeast, Rtg dependent signalling is the first found major pathway through which mitochondria communicates with nucleus. Rtg1p and Rtg3p are basic helix-loop-helix/leucine zipper (bHLH/LeuZip) transcription factors and nuclear translocation of Rtg1/3p is dependent on partial dephosphorylation of Rtg3p. Rtg2 promotes the dephosphorylation of Rtg3p and its nuclear translocation [37]. Osmotic stress activates Hog1 SAPK. Hog1 SAPK binds to the Rtg1/3p transcription factor and allows its translocation to the nucleus [38]. (B). Mitochondrial dysfunction, such as mitochondrial DNA (mtDNA) depletion or OXPHOS inhibition, triggers mitochondrial retrograde signalling in mammalian cells. For example, mitochondrial stress can activate a $\mathrm{Ca}^{2+}$-dependent retrograde signalling that is comprised of two branches: one mediated by calcineurin for the nuclear translocation of NF- $\mathrm{KB}$ or CREB or NFAT and the other directly dependent on activation of $\mathrm{Ca}^{2+}$-dependent protein kinases, such as PKC, JNK, MAPK and CAMKIV. Horizontal transfer of healthy mitochondria from stromal cells in the TME can restore mitochondrial functions and is suggested to participate in the retrograde signalling. Emerging evidences show that ROS stimulates horizontal transfer of mitochondria $[39,40]$.

\section{Mitochondria to Nucleus Crosstalk: Mitochondria Regulates Nuclear Events}

Due to the pivotal regulatory function of the mitochondria in homeostasis, cells have regulatory systems to maintain the integrity, mass and metabolic functions of the mitochondria. The majority (1500-2000) of mitochondrial proteins are encoded by the nuclear genome, so communication among cytoplasmic, nuclear and mitochondrial compartments is essential for maintaining mitochondrial function and cellular homeostasis [41,42]. The two main signalling systems that link the mitochondria and the nucleus are nucleus to mitochondria anterograde signalling and mitochondria to nucleus retrograde signalling, which comprise bi-directional communication between the mitochondria and the nucleus. Through control of transcription and translation of genes, which directly regulate mitochondrial biogenesis, nuclear signalling to the mitochondria (anterograde signalling) regulates OXPHOS and mitochondrial biogenesis in response to environmental signals received by the nucleus [43].

Mitochondria endlessly and extensively crosstalk with the nucleus and the cytosol, activating all of transcriptional, translational and post-translational processes aimed at restoring proper mitochondrial function. Mitochondrial retrograde signalling, an emerging area of mitochondrial research, comprises signalling pathways by which dysfunctional mitochondria communicate with 
the nuclear genetic compartment to relay metabolic, oxidative and respiratory stressful conditions prevailing in the mitochondria as cellular adaptation [37,41]. Retrograde signalling is very pleiotropic with respect to its origin, functional mediators involved and the resulting phenotypes. Since it is a cellular adaptation process, retrograde signalling does not necessarily result in full restoration of mitochondrial homeostasis.

Mitochondrial dysfunction can be induced by various stress factors including low mtDNA copy number, mtDNA mutations, nDNA mutations that affect mitochondrial function, mitochondrial respiratory defects that result in changes in the mtROS levels and functional competence of respiratory chain complexes. Unfortunately, we do not have clear understanding about the identity of specific signalling molecules that can trigger the retrograde signalling so far either in yeast or mammals. Mitochondrial dysfunction can affect a complex cytosolic and mitochondrial network of protein homeostasis pathways, found and mostly studied in yeast or C. elegans [36,44,45]. By inhibiting protein synthesis and by activation of the proteasome, unfolded protein response activated by mistargeting of proteins (UPRam) is beneficial for the cells, providing a means for buffering the consequences of physiological slowdown in mitochondrial protein import and for counteracting pathologies that are caused or contributed by mitochondrial dysfunction [46]. Mitochondrial unfolded protein response (UPRmt) is a transcriptional response to increase mitochondrial localized molecular chaperones and proteases to promote the recovery of mitochondrial proteostasis [47]. UPR $\mathrm{mt}$ also results in a reduction of nuclear and mtDNA-encoded OXPHOS transcripts to reduce the substrate burden on the overwhelmed proteostasis in stressed mitochondria. In C. elegans, ATFS-1, a transcriptional factor participating in retrograde signalling, was found to limit the accumulation of OXPHOS transcripts during mitochondrial stress and also to stimulate OXPHOS recovery by matching the expression of OXPHOS genes to the proteostatic capacity of mitochondria [48]. However, to our knowledge, it is currently unknown whether direct regulators of retrograde signalling other than G-Protein pathway suppressor 2 (GPS2), yet to be identified, exist in mammals [49].

From studies regarding metabolic diseases, inflammation and cancer, we have a lengthy list of key small molecules, participating in retrograde signalling, including but not limited to, ROS [50,51], NAD+/NADH ratio [52,53], acetyl-CoA [54,55], ATP [56], $\mathrm{Ca}^{2+}[57,58]$ and oncometabolites $[59,60]$. Depending on cell type and conditions, there are essentially two branches in $\mathrm{Ca}^{2+}$ mediated retrograde signalling pathway: (1) $\mathrm{Ca}^{2+} /$ calcineurin-mediated retrograde signalling for the nuclear translocations of transcription factors, NF-KB [61], NFAT, CREB and HnRNPA2 [41,62,63]; and (2) direct activation of $\mathrm{Ca}^{2+}$-dependent protein kinases, such as PKC, JNK, MAPK and CAMKIV [61,64]. Activation of these signalling pathways in epithelial cells converges on the upregulation of genes affecting several cellular functions, including apoptosis resistance, multi-drug resistance, invasion and EMT (Figure 1). Oncometabolites are metabolites whose abundance is significantly increased in cancer cells compared to normal cells. Increasing evidence shows that oncometabolites contribute to cancer progression. In addition, we advise our readers to refer to several excellent articles with more detailed information about retrograde signalling involved in epigenetic changes $[37,41,65]$ and posttranslational modifications of proteins including c-Src, MAPK, AMPK, PARPs, SIRT1 [26,66,67], in diverse pathological conditions.

Considerable attention is given to these mitochondrial stresses because they drive both beneficial and pathogenic adaptive responses [68]. Retrograde signalling appears to be capable of affecting a wide range of processes in cancer progression including activating signalling pathways that regulate metabolic adaptation, antioxidant systems, cellular proliferation, apoptosis-resistance, chemo-resistance and cellular migration and invasion [69,70]. Emerging evidence suggests that it is responsible for metabolic flexibility observed between different cancers and even between cancer cells in the same cancer tissue. Indeed, mitochondria-to-nucleus retrograde signalling in cancer may be a highly plausible mechanism by which altered mitochondrial function modulates adaptive changes in nuclear gene expression and metabolism mediated by specific transcription factors $[62,64]$ towards enhanced tumorigenesis and invasiveness. In addition, we are beginning to gather seemingly 
still fragmentary but highly important evidence suggesting that mitochondria can regulate several important nuclear events including genetic and epigenetic changes in cancer cells [17,41,71].

Reduced mtDNA content has been associated with aggressive features including a metabolic shift to glycolysis, apoptosis and increased invasiveness in multiple cancer types, such as prostate [72-74] and colorectal [75] cancers. However, caution must be taken in interpreting these findings because we do not have enough convincing data to show that retrograde signalling actually engages in the whole stages of cancer progression. Cancer cell proliferation in primary sites, intravasation, survival, migration in blood vessels, extravasation and colonization of tumour cells in distant sites are distinct steps in cancer progression. It has been suggested that retrograde signalling actually counts in the late stage of gene expression reprogramming that alters the metabolic phenotype during malignant transformation [76]. Mitochondrial dysfunction induced by mtDNA depletion promotes EMT in breast epithelial cells through a $\mathrm{Ca}^{2+}$ / calcineurin-mediated mitochondrial retrograde signalling that triggers transcriptional activation of SLUG, SNAIL and TWIST, MMP-9 and the mesenchymal markers, vimentin, fibronectin and $\mathrm{N}$-cadherin, with a corresponding decrease in the epithelial marker, E-cadherin [77]. Of note, reduced mtDNA content has been directly correlated with induction of EMT through activation of mitochondria-to-nucleus signalling $[27,70]$ and revitalization of OXPHOS is commonly observed in cancer cells undergoing EMT [16,78-81]. The changes in mitochondrial genome are likely metastasis modifiers rather than drivers [28].

There is accumulating evidence that mtDNA can be transferred between cells or species [79,80,82-84]. Mitochondria can move from one cell to another by various intercellular structures such as tunnelling nanotubes (TNTs) or cytoplasmic bridges [84,85]. Mesenchymal stem cells (MSCs) sense mitochondria released from damaged cells as danger signals to activate their rescue properties for the damaged cells [86]. Foreign mitochondria from damaged cells were engulfed and degraded by MSC, leading to induction of the cytoprotective enzyme heme oxygenase- 1 and stimulation of mitochondrial biogenesis in MSC. As a result, the rescue capacity of MSC to transfer their mitochondria to injured cells to combat oxidative stress injury was enhanced. Horizontal transfer of mtDNA from the host cells in the TME to cancer cells with compromised respiratory function to re-establish respiration and metastatic efficacy was also recently shown $[80,84,87]$. Transfer of mitochondria between leukemic cells and bone marrow mesenchymal stem cells is increased by chemotherapy [39]. It has been shown that uptake of mitochondria by leukemic cells increases oxidative phosphorylation and favours survival, indicating new insights into a novel mechanism of drug resistance $[88,89]$. Another report also showed that cancer cells uptaking mitochondria displayed chemoresistance, indicating functional aspects of mitochondrial acquisition beyond respiration recovery [90]. It may be feasible that interfering with transfer of mtDNA together with targeting OXPHOS metabolism would be an efficient adjuvant strategy to affect the intrinsic crucial metabolic function of cancer cells and the supportive function of TME. Some of the outstanding questions would be (1) what are mechanisms that are responsible for the transfer of host mtDNA to cancer cells in TME? (2) can mtDNA from dysfunctional mitochondria in cancer cells move to the host cells in turn? (3) would the metabolic profiles of the host cells in the TME be affected from the mtDNA transferred from cancer cells? and (4) does the transfer of mtDNA extend the spectrum of retrograde signalling as communication between different cells?

\section{Oncometabolites from Dysfunctional Mitochondria}

Increasing evidence shows that oncometabolites, participating in the retrograde signalling, contribute to cancer progression. For now, the list of established oncometabolites is very short and consists of 2-hydroxyglutarate (2HG), succinate and fumarate, that result from oncogenic mutations in isocitrate dehydrogenase (IDH), succinate dehydrogenase (SDH) or fumarate hydratase (FH), respectively [60]. Since their function is often regulated by both their substrate and the product, metabolic enzymes can directly sense the supply and demand of nutrients. Thus, the capability of metabolic enzymes to both sense metabolic stress and also regulate nuclear gene transcription 
is an efficient way by which an adaptive response can be achieved. A major functional mechanism of $2 \mathrm{HG}$ is their structural similarity to $\alpha-K G$, which allows $2 \mathrm{HG}$ to act as a competitive inhibitor of $\alpha$-KG-dependent enzymes including the Jumonji-C domain containing histone demethylase (JMJD/JHDM) and the 10-11-translocation methylcytosine dioxygenase (TET) families of chromatin-modifying enzymes and the prolyl hydroxylases (PHD) family [91]. The TCA cycle intermediate, $\alpha-K G$, is a co-substrate for many enzymes in the cytoplasm and the nucleus, including JMJD/JHDM and TET families of chromatin-modifying enzymes and the PHD family. Glutamine-derived $\alpha$-KG contributes to TET-dependent demethylation reactions [92]. Mutant versions of cytoplasmic and mitochondrial IDH isoforms, IDH1 and IDH2, respectively, reduce $\alpha-\mathrm{KG}$ to generate 2HG [93]. Therefore, through the production of oncometabolite 2HG, mitochondria exert a strong influence on chromatin structure associated with DNA hypermethylation and cause a broad epigenetic change to promote cancer progression $[59,94]$. 2HG also inhibits the enzymatic activity of cytochrome c oxidase and ATP synthase [70,95] and alters the gene expression of TCA cycle enzymes in cancer cells [96]. These findings suggest that the accumulation of $2 \mathrm{HG}$ contributes to the changes in energy metabolism in IDH-mutant cancer cells.

Succinate and fumarate accumulation resulting from mutations in $\mathrm{SDH}$ and $\mathrm{FH}$, respectively, stabilize HIF- $1 \alpha$ via PHD inhibition, reinforcing the Warburg effect [91,97]. Accumulation of fumarate and succinate also inhibits the $\alpha$-KG dependent histone and DNA methylases, the JMJD/JHDM and TET family of proteins, respectively [98-101]. The accumulation of intracellular fumarate can result in the succination modification of cysteine residues within the Keap1 and results in an increase in levels of NRF2 from abrogation of Keap1-mediated degradation of NRF2 [102]. NRF2, acetylated by transcription coactivator and acetyltransferase, p300, activates several antioxidant genes and supports cancer formation. Decreased level of FH can increase the levels of both NRF1 and NRF2 [103] and NRF1 also promotes mesenchymal transition and spheroid survival in mammary epithelial cells by stimulating OXPHOS [81]. Activating mutations of NRF2 or treatment of cancer cells with antioxidants can not only reduce level of ROS but also turn on oncogenic activities [104]. Additionally, the accumulation of fumarate might promote tumorigenesis by inhibiting $\alpha$-KG-dependent genome-wide histones and DNA methylations, resulting in epigenetic alterations in gene expression [101] or by increasing ROS dependent signalling via generation of succinated glutathione [105]. Fumarate can increase histone H3 methylation by inhibiting KDM2B demethylase and promote binding of DNA-dependent protein kinase and the recruitment of end-processing enzymes for DNA repair $[101,106,107]$. In conclusion, mutations in mitochondrial metabolic enzymes, IDH2, SDH or FH, results in abundant oncometabolites and leads to epigenetic changes, further dysfunction of mitochondria, production of ROS, cancer progression and notably, increased EMT. Table 1 summarizes functions and producers of oncometabolites.

Table 1. Summary of oncometabolites.

\begin{tabular}{|c|c|c|c|}
\hline Metabolites & Producer & Specific Function & Common Function \\
\hline Acetyl CoA & PDC & $\begin{array}{l}\text { Produces acetyl-CoA and increases histone } \\
\text { acetylation. Increases the expression of genes that } \\
\text { promote cell cycle progression and cell proliferation }\end{array}$ & \\
\hline 2-hydroxybutyrate & Mutated IDH & Inhibits cytochrome c oxidase and ATP synthase. & \\
\hline Fumarate & WT SDH, mutated FH & $\begin{array}{l}\text { Inhibits Keap1-mediated degradation of NRF. } \\
\text { Increases ROS signalling via generation of } \\
\text { succinated glutathione. Inhibits the demethylase } \\
\text { KDM2B, increases H3 methylation and promotes } \\
\text { binding of DNA-dependent protein kinase and the } \\
\text { recruitment of end-processing DNA repair enzymes. }\end{array}$ & \multirow[t]{2}{*}{$\begin{array}{l}\text { Inhibits the JMJD family, TET family and } \\
\text { PHD family. Increased methylation } \\
\text { promotes the expression of genes increasing } \\
\text { proliferation and inhibiting differentiation. }\end{array}$} \\
\hline Succinate & Mutated SDH & & \\
\hline Phosphoenolpyruvate (PEP) & PKM2 & $\begin{array}{l}\text { Phosphorylation of } \mathrm{H} 3 \text { with PEP facilitates H3 } \\
\text { acetylation, promotes expression of c-Myc and } \\
\text { cyclin D1. STAT3 phosphorylation promotes } \\
\text { MEK5 activation. }\end{array}$ & \\
\hline
\end{tabular}




\section{Nuclear Metabolic Enzymes as New Regulators of Retrograde Signalling}

Recent updates indicate that many metabolic enzymes found in the cytosol or mitochondria can move to the nucleus and have non-canonical functions [71,108-111], directly linking metabolism with gene transcription, particularly epigenetic mechanisms such as methylation of DNA and histones or acetylation of histones. These findings suggest that metabolic enzymes themselves can participate in the retrograde signalling from their non-canonical function in the nucleus. Both cytoplasmic pyruvate kinase (PKM2) and mitochondrial pyruvate dehydrogenase complex (PDC) can translocate to the nucleus and form a complex with p300, which locally produces acetyl-CoA to acetylate histones and can facilitate locally confined specific gene transcription [111,112]. Nuclear PKM2 produces pyruvate from phosphoenolpyruvate (PEP), which is used by PDC for the production of acetyl-CoA, which in turn phosphorylates histone H3 [110] and STAT3 [109], as a novel non-canonical kinase using PEP instead of ATP as the phosphate donor. Like acetylation, phosphorylation of $\mathrm{H} 3$ is also an important histone modification, which promotes cell-cycle progression and cancer growth by increasing the expression of cyclin D1 and c-Myc [110]. Independent of its kinase activity, PKM2 can function as a co-transcription factor, promoting HIF- $1 \alpha$ binding activity to DNA and thereby participating in a positive feedback loop with HIF-1 $\alpha$, which upregulates several glycolytic enzymes including PKM2 itself [113,114]. Nuclear PDC levels are increased in a cell-cycle-dependent manner and in response to serum or mitochondrial stress, with a concomitant decrease in mitochondrial PDC levels, suggesting a translocation of PDC from the mitochondria to the nucleus [112]. Indeed, whole-transcriptome analysis revealed that mitochondria have the ability to regulate the expression of more than $66 \%$ of genes within the human genome, including the epigenetic/chromatin remodelling machineries $[115,116]$. Acetyl-CoA can influence posttranslational acetylation on histone tails and change the nuclear epigenome both globally throughout the nucleus and locally for specific histones and proteins. Translocation of mitochondrial PDC to the nucleus promotes acetyl-CoA synthesis in the nucleus, which is required for histone acetylation and epigenetic regulation [112]. Nuclear PDC increases acetylation of specific lysine residues on histones, upregulates expression of phosphorylated Rb, E2F, Cdk2 and cyclin A and promotes G1-S phase progression and expression of $S$ phase markers [112,117]. Mitochondrial stress activates Akt1 and Akt1 mediates transcription activation via phosphorylation and activation of p300 [118]. Acetylation of PKM2 by p300 promotes its nuclear translocation and its non-canonical function as a transcription regulator and a kinase, respectively [119]. Acetylation of the c-Myc oncoprotein by p300 increases its stability and the transcription of its target genes [120], also suggesting a link between mitochondrial stress, acetylation events in the nucleus and cancer progression. Of note, mitochondrial stress can promote nuclear translocation of PDC [112], in addition to the nuclear translocation of cytosolic PKM2, indicating that nuclear translocation of mitochondrial enzyme can be triggered by mitochondrial dysfunction. Our Figure 2 shows a functional summary of nuclear PKM2 and PDC.

Other glycolytic enzymes such as hexokinase 2 (HK2), lactate dehydrogenase (LDH) and 3-phosphoglycerate kinase (PGK) can also move to the nucleus and perform their non-canonical functions. HK2 is an enzyme catalysing the first committed step of glycolysis and found overexpressed in many cancer cells. In the nucleus of HeLa cells, HK2 is found in nucleus and low glucose environment or Akt inhibition augments their nuclear localization [121,122]. In yeast, HK2 regulates its incorporation into the repressor complex of the Mig1-dependent gene promoters in response to cytoplasmic glucose level, indicating its role as a fuel sensor regulating expression of other metabolic enzymes [123]. Y238 phosphorylation of LDH is important for the nuclear translocation, although upstream molecule responsible for the phosphorylation is not clear [124,125]. Nuclear LDH is increased under oxidative stress [126] and binds DNA, stimulates UV-induced DNA repair [127]. Nuclear LDH is also increased by E7-induced ROS accumulation in cervical cancer cells, performs a non-canonical enzyme activity to produce $\alpha$-hydroxybutyrate and triggers DOT1L mediated histone H3K79 hypermethylation, resulting in the activation of antioxidant responses and Wnt signalling pathway in cervical cancer cells [128]. PGK stimulates DNA synthesis catalysed by DNA polymerase 
$\alpha$ and $\varepsilon$ on single-stranded DNA [127]. LDH in nucleus can also interact with SIRT1 and regulate epigenetic modifications by manipulating NAD+, indicating an intricate link between metabolism and the processing of genetic information [126].

We anticipate that further studies on the identification of metabolic triggers that enable nuclear translocation of metabolic enzymes will reveal that specific nuclear metabolic enzymes are potent participants of the retrograde signalling.

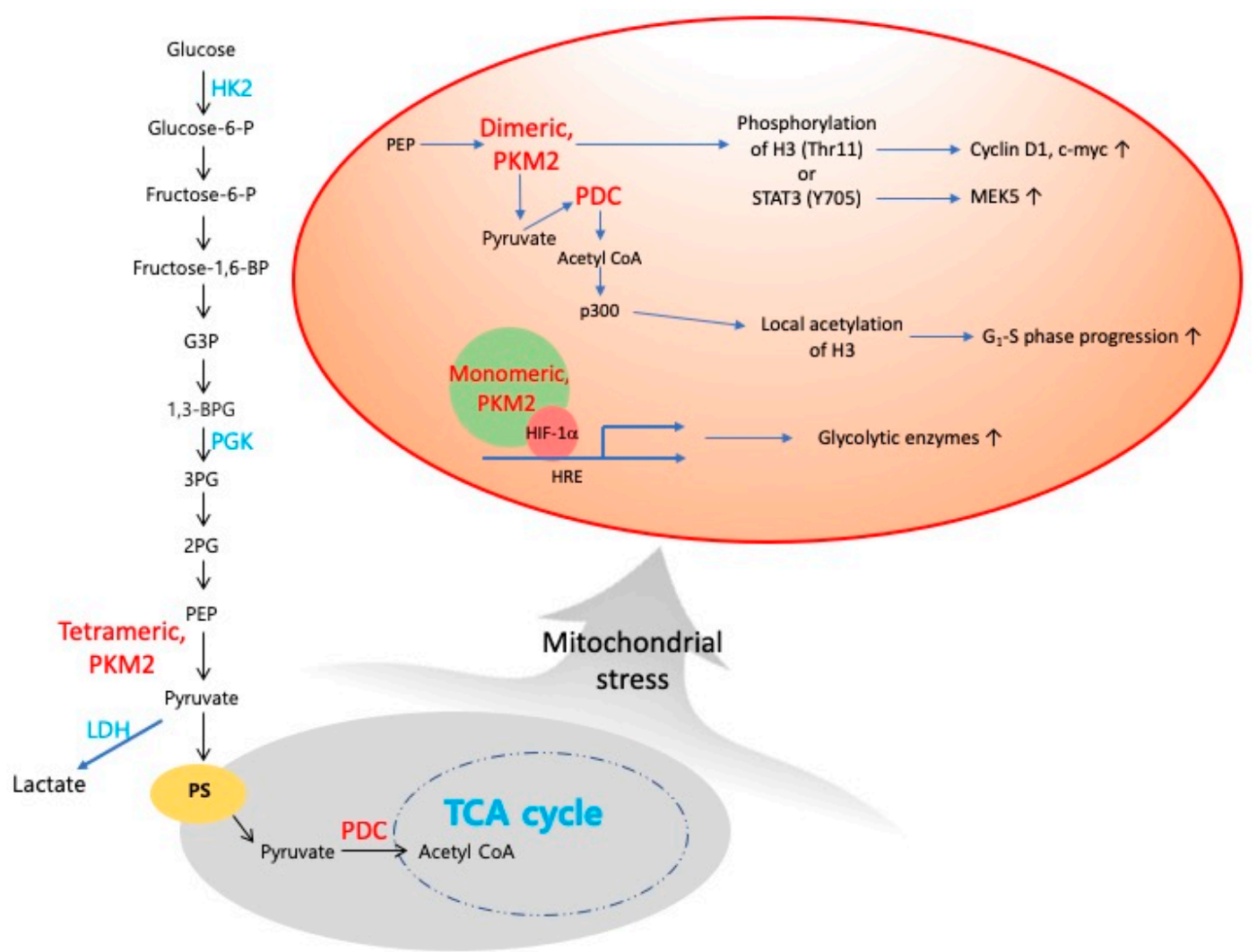

Figure 2. Translocation of PKM2 or PDC into nucleus, where it serves as transcriptional coactivator and as a protein kinase or as a producer of acetyl CoA to modulate transcriptional program. In nucleus, dimeric PKM2 becomes a protein kinase using PEP as a phosphate donor. PKM2 is able to phosphorylate STAT3 at Y705 and promotes transcription of MEK5. PKM2 directly binds to and phosphorylates histone $\mathrm{H} 3$ at threonine 11 upon epidermal growth factor (EGF) receptor activation [109]. PKM2 can function as a transcriptional coactivator, promoting HIF-1 $\alpha$ binding activity to DNA and thereby participating in a positive feedback loop with HIF-1 $\alpha$ [114]. Grey circle denotes mitochondrial events and orange circle indicates nuclear events. Subcellular localization of glycolytic metabolites and tetrameric PKM2 is in cytoplasm. PKM2 and PDC are shown in red. Canonical cytosolic functions of HK2, LDH and PGK are shown here in blue. Abbreviations: G3P, glyceraldehyde 3-phosphate; 3PG, 3-phosphoglyceraste; 2PG, 2-phosphoglyceraste; PEP, phosphoenolpyruvate; PDC, pyruvate dehydrogenase complex; PS, pyruvate symporter.

\section{Retrograde Signalling and Metabolic Switching in the Tumour Microenvironment}

Cancer-related non-resolving inflammation in the TME is a hallmark of cancer. TME is generally hypoxic, ROS rich and an acidic environment. Recent findings clearly show that both, a shift to Warburg effect or OXPHOS or combined metabolic phenotypes exist in rapidly proliferating cells, including various types of immune cells, most notably in macrophages and T cells and determine the function of the immune cell subsets in disease conditions such as those in inflamed tissue, obese adipose tissue or cancer [129-132]. For example, due to metabolic needs to maintain a higher level of ATP, tolerogenic dendritic cells show the highest OXPHOS activity and production of ROS, increased spare respiratory 
capacity and more pronounced glycolytic capacity and reserve compared to immunogenic mature dendritic cells [133].

M1-associated inhibition of mitochondrial OXPHOS is the factor responsible for preventing M1-like to M2-like activation [134] and glycolytic stimulation is not required for M2-like activation when OXPHOS is intact [135], indicating that metabolism determines macrophage activation. M2-like activated macrophages exploit FAO to fuel OXPHOS, rather than aerobic glycolysis that M1-like proinflammatory activated macrophages exploit for ATP production [136-138]. The reports that inhibition of ROS from ETC with metformin [139] or activation of AMPK with AICAR promotes M1 like to M2 like activation [140] indicate that boosting FAO or OXPHOS can be suggested to switch macrophage class from M1-like to M2-like [141]. A "shift" from OXPHOS to aerobic glycolysis is a hallmark of $\mathrm{T}$ cell activation [130]. T cells, if not activated, show low levels of metabolic requirements, use OXPHOS to maximize production of ATP as an energy source and engage scarcely in biosynthesis, whereas activated $\mathrm{T}$ cells use aerobic glycolysis to produce effector molecules for rapid cellular proliferation [138]. Mitochondrial oxidative metabolism supports immunosuppression and lineage commitment of Tregs [142-144]. Cancer aggressiveness is promoted by metabolic synergy between cancer cells and stromal cells [145]. Metabolic synergy induces efficient utilization of catabolites by cancer cells in TME [24] and cancer cells induce aerobic glycolysis in neighbouring fibroblasts by providing a hypoxic ROS-rich microenvironment [24,146]. Induced fibroblasts differentiate to myofibroblasts and upregulate MCT4 to secrete lactate and pyruvate that transform the normal stroma to ultimately help cancer cells grow (the Reverse Warburg effect). All these findings indicate that cells in the TME show mixed metabolic phenotypes of aerobic glycolysis and OXPHOS, resulting from various interactions between different cells or metabolic stress (Figure 3).

Therefore, with metabolic regulation via suppression of aerobic glycolysis and concomitant promotion of OXPHOS, would it be possible that mitochondrial retrograde signalling, an adaptive mechanism to restore mitochondrial homeostasis in response to mitochondrial stress, can also participate in activation of immune cells? If yes, is it responsible for the metabolic flexibility in the TME? It appears that we have some answers suggesting that retrograde signalling can suppress glycolysis and promote OXPHOS in myeloid cells. Mitochondrial ROS is important both for M1-like and M2-like activation $[147,148]$ and can induce retrograde signalling by alterations in mitochondrial membrane potential $(\Delta \psi \mathrm{m})$ and activation of $\mathrm{Ca}^{2+} /$ calcineurin dependent factors, suggesting an involvement of the retrograde signalling pathway in M1-like to M2-like activation. Indeed, in murine macrophages, mitochondrial dysfunction induced by hypoxic insult or ATP synthase inhibitor, activates $\mathrm{Ca}^{2+}$ /calcineurin or mediated retrograde signalling pathway with activation of AMPK and NF- $\mathrm{KB}$, in which ROS induced mitochondrial membrane damage is a component of the signalling pathway $[149,150]$. Of note, the regulators involved in macrophage M2-like activation are also shared by the retrograde signalling pathway. Depletion of glucose or a glucose-rich hypoxic ROS environment favours M2-like activation or M1-like activation of macrophages, respectively and depletion of glucose can disarm T cells in the TME [132,151]. Low levels of ATP due to dietary restrictions or energy consumption, induce expression of nicotinamide phosphoribosyl transferase that generates $\mathrm{NAD}^{+}$, which is a key factor for SIRT1 activation. SIRT1, also a regulator of retrograde signalling, acetylates and activates PGC1ß to increase OXPHOS in macrophage [152-154].

In addition, Akt activation in response to mitochondrial respiratory stress has been found in different tumour cell systems [63,72,155] and PI3K/Akt signalling also regulates macrophage activation in the TME. The PI3K regulator lipid phosphatase, phosphatase and tensin homolog (PTEN), contributes to macrophage polarization because deletion of PTEN and resultant activation of PI3K/Akt signalling results in increased M2-like activation [156,157]. Interestingly, deletion of Akt1 promotes upregulation of inducible NO synthase and IL-12 $\beta$ (M1-like activation) and Akt2 deficiency in macrophages highlights the opposing roles of Akt isoforms in macrophage polarization, because Akt2-/ - macrophages possess an M2-like phenotype [158]. These findings suggest that mitochondrial stress induced retrograde signalling can determine the activation of myeloid cells. 
Tumour suppressor p53 is critically important in preventing oncogenesis but its role in inflammation in general and in the function of inflammatory macrophages in particular is not certain. Mitochondrial stress induced by doxorubicin or partial depletion of mtDNA ( 70\%) activates the Ca2+/calcineurin retrograde signalling pathway, inducing expression of $\mathrm{p} 53$, which in turn attenuates HIF- $1 \alpha$ activity in multiple types of cells [159-161]. p53 mediated suppression of HIF- $1 \alpha$ controls regulation of glycolysis and 'loss of function mutation' of p53 is partially responsible for enhanced glycolysis in cancer cells [162]. Notably, deletion or activation of p53 in myeloid cells represses or induces the M2-like phenotype, respectively, in a chronic inflammatory venous thrombus model [163]. However, conflicting reports that p53 drives M1-like phenotype in tumour-associated macrophages (TAMs) of several cancer models [164-166] do not support this speculation, possibly indicating pathological differences in different microenvironments or in different model systems.

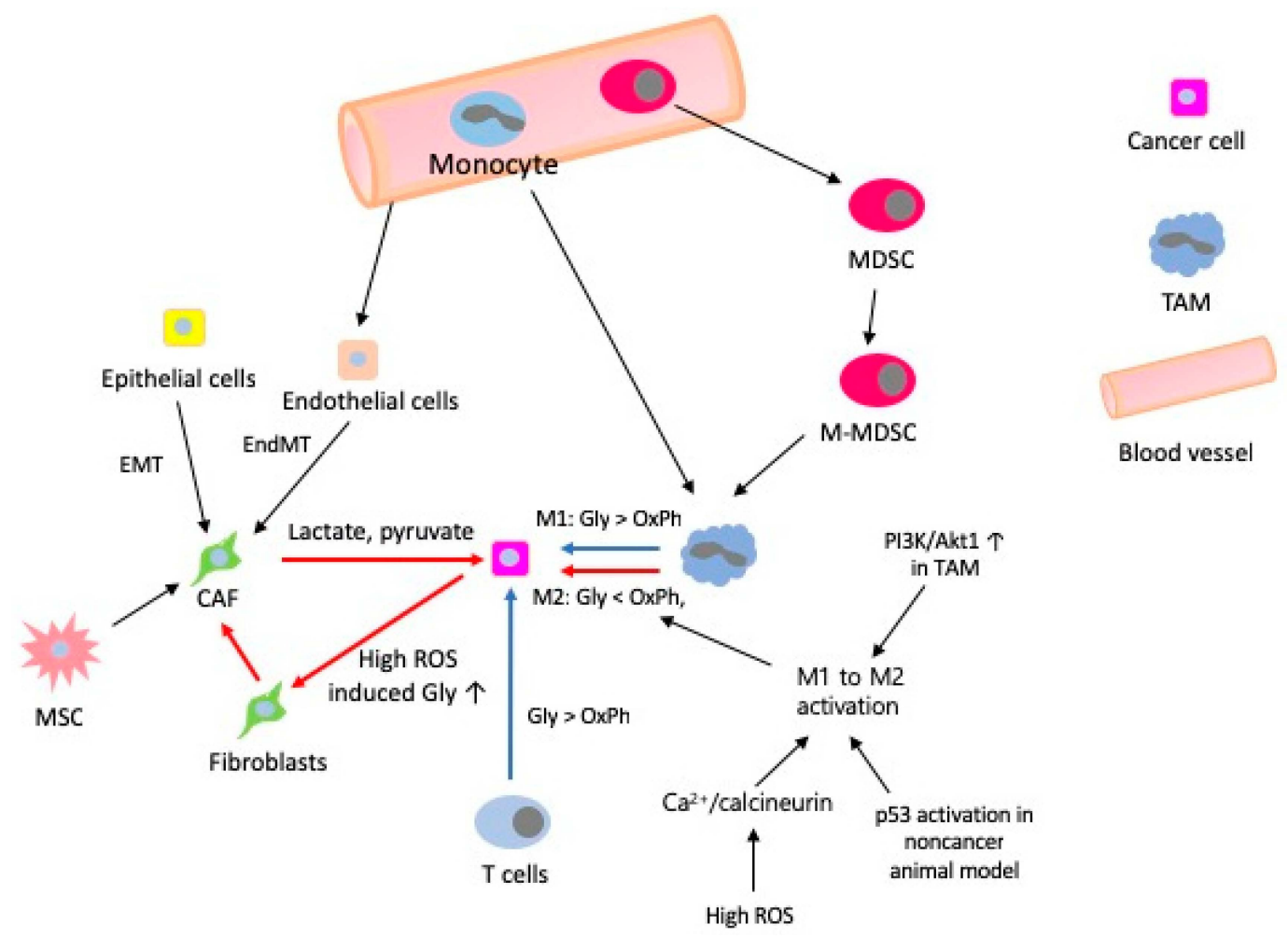

Figure 3. Summary of metabolic switching in the TME. Red arrows indicate immune suppressive response favourable to growth and survival of cancer cells. Blue arrows indicate immune stimulatory response detrimental to cancer cells. Abbreviations: EndMT, endothelial to mesenchymal transition; Gly, aerobic glycolysis; MDSC, myeloid derived suppressor cell; M-MDSC, monocytic myeloid derived suppressor cell; $\mathrm{OxPh}$, oxidative phosphorylation; TAM, tumour-associated macrophage.

\section{Conclusions}

Many important questions about the involvement of retrograde signalling pathways in cancer biology, for example, the specific sensors of different types of mitochondrial stress and the cell and tissue specificity of the signalling responses, are yet to be explored. Importantly, with a list of small molecules and potential protein regulators involved in retrograde signalling, it appears that we still do not clearly understand the identity of specific signalling molecules that can trigger the retrograde signalling so far either in yeast or mammals. In addition, what determines whether retrograde signalling results in beneficial or maladaptive responses, its significance in determination of cancer progression and which cell type in the TME is mostly affected, should be identified. For now, relevant studies are largely limited by the difficulty of experimentally manipulating mtDNA in cancer cells and the lack of animal models with mtDNA mutations. It is not technically feasible at this 
moment to differentiate mtDNA abnormalities in host cells from those of the cancer cells in the TME. Would it be possible for mtDNA from cancer cells to move to and affect the non-transformed host stromal cells that have no genetic or epigenetic changes? Indeed, intercellular structures such as TNTs have been involved in the transfer of mitochondria between different cells. Thus, are such structures involved in the retrograde signalling and responsible for the communication between cells in the TME? Further studies on the horizontal transmission of mitochondrial retrograde signalling between diverse cells in the TME may also extend our understanding of cancer progression. As stated, retrograde signalling may suppress glycolysis and promote OXPHOS in myeloid cells, indicating a possibility that the retrograde signalling may regulate glycolysis in some type of cancer cells whose metabolism and genetic or epigenetic events are rewired. If it actually happens, this will also extend our understanding about functional implications of retrograde signalling. Finally, we expect the feasibility of future approaches, targeting retrograde signalling for successful cancer therapy from suppression of metastasis or resistance to drugs, to become an exciting topic of study in the near future.

Funding: This work was supported by the Basic Science Research Program, through the National Research Foundation of Korea (NRF), funded by the Ministry of Science, ICT \& Future Planning (NRF-2017R1D1A1B03029063) and by the Korean Government (NRF-2018R1D1A1B07041381).

Conflicts of Interest: The authors declare no conflict of interest.

$\begin{array}{ll}\text { Abbreviations } \\ \text { AICAR } & \text { 5-Aminoimidazole-4-carboxamide ribonucleotide } \\ \text { AMPK } & \text { 5' AMP-activated protein kinase } \\ \text { ATFS-1 } & \text { Activating transcription factor associated with stress-1 } \\ \text { CAMKIV } & \text { Calcium/calmodulin-dependent protein kinase type IV } \\ \text { CREB } & \text { cAMP response element-binding protein } \\ \text { DOT1L } & \text { Disruptor of telomeric silencing 1-like } \\ \text { EMT } & \text { Epithelial to mesenchymal transition } \\ \text { ETC } & \text { Electron transfer chain } \\ \text { FAO } & \text { Fatty acid oxidation } \\ \text { HIF-1 } \alpha & \text { Hypoxia-inducible factor-1 } \alpha \\ \text { JNK } & \text { c-Jun N-terminal kinase } \\ \text { Keap1 } & \text { Kelch-like ECH-associated protein 1 } \\ \alpha \text {-KG } & \alpha \text {-Ketoglutarate } \\ \text { MAPK } & \text { Mitogen-activated protein kinas } \\ \text { MCT4 } & \text { Monocarboxylate transporter 4 } \\ \text { MMP-9 } & \text { Matrix metalloproteinases-9 } \\ \text { mtDNA } & \text { Mitochondrial DNA } \\ \text { nDNA } & \text { Nuclear DNA } \\ \text { NF- } B \text { B } & \text { Nuclear factor kappa-light-chain-enhancer of activated B cell } \\ \text { NFAT } & \text { Nuclear factor of activated T-cells } \\ \text { NO } & \text { Nitric oxide } \\ \text { NRF2 } & \text { Nuclear factor erythroid 2-related factor 2 } \\ \text { OXPHOS } & \text { Oxidative phosphorylation } \\ \text { PARP } & \text { Poly (ADP-ribose) polymerase } \\ \text { PGC1ß } & \text { Peroxisome proliferator-activated receptor gamma coactivator 1-alpha } \\ \text { PI3K } & \text { Phosphoinositide 3-kinase } \\ \text { PKC } & \text { Protein kinase C } \\ \text { ROS } & \text { Reactive oxygen species } \\ \text { SAPK } & \text { Stress-activated protein kinase } \\ \text { SIRT1 } & \text { Silent mating type information regulation 2 homolog 1/Sirtuin } \\ \text { STAT3 } & \text { Signal transducer and activator of transcription 3 } \\ \text { TCA cycle } & \text { Tricarboxylic acid cycle/Krebs cycle } \\ \text { Treg } & \text { regulatory T cell } \\ & \end{array}$




\section{References}

1. Rose, G.; Santoro, A.; Salvioli, S. Mitochondria and mitochondria-induced signalling molecules as longevity determinants. Mech. Ageing Dev. 2017, 165, 115-128. [CrossRef]

2. Potter, M.; Newport, E.; Morten, K.J. The Warburg effect: 80 years on. Biochem. Soc. Trans. 2016, 44, 1499-1505. [CrossRef] [PubMed]

3. Weinhouse, C. Mitochondrial-epigenetic crosstalk in environmental toxicology. Toxicology 2017, 391, 5-17. [CrossRef] [PubMed]

4. Wei, Y.; Chen, L.; Xu, H.; Xie, C.; Zhou, Y.; Zhou, F. Mitochondrial Dysfunctions Regulated Radioresistance through Mitochondria-to-Nucleus Retrograde Signaling Pathway of NF-kB/PI3K/AKT2/mTOR. Radiat. Res. 2018, 190, 204-215. [CrossRef] [PubMed]

5. Vander Heiden, M.G.; Cantley, L.C.; Thompson, C.B. Understanding the Warburg effect: The metabolic requirements of cell proliferation. Science 2009, 324, 1029-1033. [CrossRef]

6. Ward, P.S.; Thompson, C.B. Metabolic reprogramming: A cancer hallmark even warburg did not anticipate. Cancer Cell 2012, 21, 297-308. [CrossRef] [PubMed]

7. Schulze, A.; Harris, A.L. How cancer metabolism is tuned for proliferation and vulnerable to disruption. Nature 2012, 491, 364-373. [CrossRef]

8. Koppenol, W.H.; Bounds, P.L.; Dang, C.V. Otto Warburg's contributions to current concepts of cancer metabolism. Nat. Rev. Cancer 2011, 11, 325-337. [CrossRef]

9. Wallace, D.C. Mitochondria and cancer. Nat. Rev. Cancer 2012, 12, 685-698. [CrossRef]

10. Lu, J.; Tan, M.; Cai, Q. The Warburg effect in tumor progression: Mitochondrial oxidative metabolism as an anti-metastasis mechanism. Cancer Lett. 2015, 356, 156-164. [CrossRef]

11. Zheng, J. Energy metabolism of cancer: Glycolysis versus oxidative phosphorylation (Review). Oncol. Lett. 2012, 4, 1151-1157. [CrossRef] [PubMed]

12. Chandra, D.; Singh, K.K. Genetic insights into OXPHOS defect and its role in cancer. Biochim. Biophys. Acta 2011, 1807, 620-625. [CrossRef] [PubMed]

13. Owens, K.M.; Kulawiec, M.; Desouki, M.M.; Vanniarajan, A.; Singh, K.K. Impaired OXPHOS complex III in breast cancer. PLoS ONE 2011, 6, e23846. [CrossRef]

14. Lopez-Rios, F.; Sanchez-Arago, M.; Garcia-Garcia, E.; Ortega, A.D.; Berrendero, J.R.; Pozo-Rodriguez, F.; Lopez-Encuentra, A.; Ballestin, C.; Cuezva, J.M. Loss of the mitochondrial bioenergetic capacity underlies the glucose avidity of carcinomas. Cancer Res. 2007, 67, 9013-9017. [CrossRef] [PubMed]

15. Moreno-Sanchez, R.; Rodriguez-Enriquez, S.; Marin-Hernandez, A.; Saavedra, E. Energy metabolism in tumor cells. FEBS J. 2007, 274, 1393-1418. [CrossRef] [PubMed]

16. LeBleu, V.S.; O'Connell, J.T.; Gonzalez Herrera, K.N.; Wikman, H.; Pantel, K.; Haigis, M.C.; de Carvalho, F.M.; Damascena, A.; Domingos Chinen, L.T.; Rocha, R.M.; et al. PGC-1alpha mediates mitochondrial biogenesis and oxidative phosphorylation in cancer cells to promote metastasis. Nat. Cell Biol. 2014, 16, 992-1003, 1001-1015. [CrossRef] [PubMed]

17. Wallace, D.C.; Fan, W. Energetics, epigenetics, mitochondrial genetics. Mitochondrion 2010, 10, $12-31$. [CrossRef]

18. Galluzzi, L.; Kepp, O.; Vander Heiden, M.G.; Kroemer, G. Metabolic targets for cancer therapy. Nat. Rev. Drug Discov. 2013, 12, 829-846. [CrossRef] [PubMed]

19. Pietras, K.; Ostman, A. Hallmarks of cancer: Interactions with the tumor stroma. Exp. Cell Res. 2010, 316, 1324-1331. [CrossRef] [PubMed]

20. Kim, J. Regulation of Immune Cell Functions by Metabolic Reprogramming. J. Immunol. Res. 2018, 2018, 8605471. [CrossRef] [PubMed]

21. Michalek, R.D.; Rathmell, J.C. The metabolic life and times of a T-cell. Immunol. Rev. 2010, 236, 190-202. [CrossRef] [PubMed]

22. Altman, B.J.; Dang, C.V. Normal and cancer cell metabolism: Lymphocytes and lymphoma. FEBS J. 2012, 279, 2598-2609. [CrossRef]

23. Doherty, J.R.; Cleveland, J.L. Targeting lactate metabolism for cancer therapeutics. J. Clin. Investig. 2013, 123, 3685-3692. [CrossRef] [PubMed]

24. Martinez-Outschoorn, U.; Sotgia, F.; Lisanti, M.P. Tumor microenvironment and metabolic synergy in breast cancers: Critical importance of mitochondrial fuels and function. Semin. Oncol. 2014, 41, 195-216. [CrossRef] 
25. Sonveaux, P.; Vegran, F.; Schroeder, T.; Wergin, M.C.; Verrax, J.; Rabbani, Z.N.; De Saedeleer, C.J.; Kennedy, K.M.; Diepart, C.; Jordan, B.F.; et al. Targeting lactate-fueled respiration selectively kills hypoxic tumor cells in mice. J. Clin. Investig. 2008, 118, 3930-3942. [CrossRef] [PubMed]

26. Jia, D.; Park, J.H.; Jung, K.H.; Levine, H.; Kaipparettu, B.A. Elucidating the Metabolic Plasticity of Cancer: Mitochondrial Reprogramming and Hybrid Metabolic States. Cells 2018, 7, 21. [CrossRef]

27. Guerra, F.; Guaragnella, N.; Arbini, A.A.; Bucci, C.; Giannattasio, S.; Moro, L. Mitochondrial Dysfunction: A Novel Potential Driver of Epithelial-to-Mesenchymal Transition in Cancer. Front. Oncol. 2017, 7, 295. [CrossRef] [PubMed]

28. Beadnell, T.C.; Scheid, A.D.; Vivian, C.J.; Welch, D.R. Roles of the mitochondrial genetics in cancer metastasis: Not to be ignored any longer. Cancer Metastasis Rev. 2018, 37, 615-632. [CrossRef]

29. Parikh, V.S.; Morgan, M.M.; Scott, R.; Clements, L.S.; Butow, R.A. The mitochondrial genotype can influence nuclear gene expression in yeast. Science 1987, 235, 576-580. [CrossRef]

30. Jazwinski, S.M.; Kriete, A. The yeast retrograde response as a model of intracellular signaling of mitochondrial dysfunction. Front. Physiol. 2012, 3, 139. [CrossRef]

31. Guaragnella, N.; Zdralevic, M.; Lattanzio, P.; Marzulli, D.; Pracheil, T.; Liu, Z.; Passarella, S.; Marra, E.; Giannattasio, S. Yeast growth in raffinose results in resistance to acetic-acid induced programmed cell death mostly due to the activation of the mitochondrial retrograde pathway. Biochim. Biophys. Acta 2013, 1833, 2765-2774. [CrossRef] [PubMed]

32. Laera, L.; Guaragnella, N.; Zdralevic, M.; Marzulli, D.; Liu, Z.; Giannattasio, S. The transcription factors ADR1 or CAT8 are required for RTG pathway activation and evasion from yeast acetic acid-induced programmed cell death in raffinose. Microb. Cell 2016, 3, 621-631. [CrossRef] [PubMed]

33. Jazwinski, S.M. The retrograde response: A conserved compensatory reaction to damage from within and from without. Prog. Mol. Biol. Transl. Sci. 2014, 127, 133-154. [CrossRef] [PubMed]

34. Guaragnella, N.; Coyne, L.P.; Chen, X.J.; Giannattasio, S. Mitochondria-cytosol-nucleus crosstalk: Learning from Saccharomyces cerevisiae. FEMS Yeast Res. 2018, 18, 88. [CrossRef]

35. Liao, X.; Butow, R.A. RTG1 and RTG2: Two yeast genes required for a novel path of communication from mitochondria to the nucleus. Cell 1993, 72, 61-71. [CrossRef]

36. Arnould, T.; Michel, S.; Renard, P. Mitochondria Retrograde Signaling and the UPR mt: Where Are We in Mammals? Int. J. Mol. Sci. 2015, 16, 18224-18251. [CrossRef] [PubMed]

37. da Cunha, F.M.; Torelli, N.Q.; Kowaltowski, A.J. Mitochondrial Retrograde Signaling: Triggers, Pathways and Outcomes. Oxid. Med. Cell. Longev. 2015, 2015, 482582. [CrossRef]

38. Ruiz-Roig, C.; Noriega, N.; Duch, A.; Posas, F.; de Nadal, E. The Hog1 SAPK controls the Rtg1/Rtg3 transcriptional complex activity by multiple regulatory mechanisms. Mol. Biol. Cell 2012, 23, 4286-4296. [CrossRef]

39. Griessinger, E.; Moschoi, R.; Biondani, G.; Peyron, J.F. Mitochondrial Transfer in the Leukemia Microenvironment. Trends Cancer 2017, 3, 828-839. [CrossRef]

40. Herst, P.M.; Dawson, R.H.; Berridge, M.V. Intercellular Communication in Tumor Biology: A Role for Mitochondrial Transfer. Front. Oncol. 2018, 8, 344. [CrossRef]

41. Guha, M.; Avadhani, N.G. Mitochondrial retrograde signaling at the crossroads of tumor bioenergetics, genetics and epigenetics. Mitochondrion 2013, 13, 577-591. [CrossRef]

42. Aon, M.A.; Cortassa, S.; Juhaszova, M.; Sollott, S.J. Mitochondrial health, the epigenome and healthspan. Clin. Sci. 2016, 130, 1285-1305. [CrossRef] [PubMed]

43. Quiros, P.M.; Mottis, A.; Auwerx, J. Mitonuclear communication in homeostasis and stress. Nat. Rev. Mol. Cell Biol. 2016, 17, 213-226. [CrossRef] [PubMed]

44. D'Amico, D.; Sorrentino, V.; Auwerx, J. Cytosolic Proteostasis Networks of the Mitochondrial Stress Response. Trends Biochem. Sci. 2017, 42, 712-725. [CrossRef] [PubMed]

45. Topf, U.; Wrobel, L.; Chacinska, A. Chatty Mitochondria: Keeping Balance in Cellular Protein Homeostasis. Trends Cell Biol. 2016, 26, 577-586. [CrossRef]

46. Wrobel, L.; Topf, U.; Bragoszewski, P.; Wiese, S.; Sztolsztener, M.E.; Oeljeklaus, S.; Varabyova, A.; Lirski, M.; Chroscicki, P.; Mroczek, S.; et al. Mistargeted mitochondrial proteins activate a proteostatic response in the cytosol. Nature 2015, 524, 485-488. [CrossRef]

47. Lin, Y.F.; Haynes, C.M. Metabolism and the UPR(mt). Mol. Cell 2016, 61, 677-682. [CrossRef] 
48. Nargund, A.M.; Fiorese, C.J.; Pellegrino, M.W.; Deng, P.; Haynes, C.M. Mitochondrial and nuclear accumulation of the transcription factor ATFS-1 promotes OXPHOS recovery during the UPR(mt). Mol. Cell 2015, 58, 123-133. [CrossRef]

49. Cardamone, M.D.; Tanasa, B.; Cederquist, C.T.; Huang, J.; Mahdaviani, K.; Li, W.; Rosenfeld, M.G.; Liesa, M.; Perissi, V. Mitochondrial Retrograde Signaling in Mammals Is Mediated by the Transcriptional Cofactor GPS2 via Direct Mitochondria-to-Nucleus Translocation. Mol. Cell 2018, 69, 757-772. [CrossRef]

50. Droge, W. Free radicals in the physiological control of cell function. Physiol. Rev. 2002, 82, 47-95. [CrossRef]

51. Chen, Y.; Azad, M.B.; Gibson, S.B. Superoxide is the major reactive oxygen species regulating autophagy. Cell Death Differ. 2009, 16, 1040-1052. [CrossRef]

52. Canto, C.; Gerhart-Hines, Z.; Feige, J.N.; Lagouge, M.; Noriega, L.; Milne, J.C.; Elliott, P.J.; Puigserver, P.; Auwerx, J. AMPK regulates energy expenditure by modulating NAD+ metabolism and SIRT1 activity. Nature 2009, 458, 1056-1060. [CrossRef] [PubMed]

53. Houtkooper, R.H.; Canto, C.; Wanders, R.J.; Auwerx, J. The secret life of NAD+: An old metabolite controlling new metabolic signaling pathways. Endocr. Rev. 2010, 31, 194-223. [CrossRef]

54. Spange, S.; Wagner, T.; Heinzel, T.; Kramer, O.H. Acetylation of non-histone proteins modulates cellular signalling at multiple levels. Int. J. Biochem. Cell Biol. 2009, 41, 185-198. [CrossRef]

55. Park, J.H.; Vithayathil, S.; Kumar, S.; Sung, P.L.; Dobrolecki, L.E.; Putluri, V.; Bhat, V.B.; Bhowmik, S.K.; Gupta, V.; Arora, K.; et al. Fatty Acid Oxidation-Driven Src Links Mitochondrial Energy Reprogramming and Oncogenic Properties in Triple-Negative Breast Cancer. Cell Rep. 2016, 14, 2154-2165. [CrossRef] [PubMed]

56. Acin-Perez, R.; Gatti, D.L.; Bai, Y.; Manfredi, G. Protein phosphorylation and prevention of cytochrome oxidase inhibition by ATP: Coupled mechanisms of energy metabolism regulation. Cell Metab. 2011, 13, 712-719. [CrossRef] [PubMed]

57. Rasola, A.; Bernardi, P. Mitochondrial permeability transition in $\mathrm{Ca}(2+)$-dependent apoptosis and necrosis. Cell Calc. 2011, 50, 222-233. [CrossRef]

58. Csordas, G.; Hajnoczky, G. SR/ER-mitochondrial local communication: Calcium and ROS. Biochim. Biophys. Acta 2009, 1787, 1352-1362. [CrossRef]

59. Chowdhury, R.; Yeoh, K.K.; Tian, Y.M.; Hillringhaus, L.; Bagg, E.A.; Rose, N.R.; Leung, I.K.; Li, X.S.; Woon, E.C.; Yang, M.; et al. The oncometabolite 2-hydroxyglutarate inhibits histone lysine demethylases. EMBO Rep. 2011, 12, 463-469. [CrossRef]

60. Yang, M.; Soga, T.; Pollard, P.J. Oncometabolites: Linking altered metabolism with cancer. J. Clin. Investig. 2013, 123, 3652-3658. [CrossRef]

61. Guha, M.; Tang, W.; Sondheimer, N.; Avadhani, N.G. Role of calcineurin, hnRNPA2 and Akt in mitochondrial respiratory stress-mediated transcription activation of nuclear gene targets. Biochim. Biophys. Acta 2010, 1797, 1055-1065. [CrossRef] [PubMed]

62. Guha, M.; Srinivasan, S.; Guja, K.; Mejia, E.; Garcia-Diaz, M.; Johnson, F.B.; Ruthel, G.; Kaufman, B.A.; Rappaport, E.F.; Glineburg, M.R.; et al. HnRNPA2 is a novel histone acetyltransferase that mediates mitochondrial stress-induced nuclear gene expression. Cell Discov. 2016, 2, 16045. [CrossRef]

63. Guha, M.; Fang, J.K.; Monks, R.; Birnbaum, M.J.; Avadhani, N.G. Activation of Akt is essential for the propagation of mitochondrial respiratory stress signaling and activation of the transcriptional coactivator heterogeneous ribonucleoprotein A2. Mol. Biol. Cell 2010, 21, 3578-3589. [CrossRef] [PubMed]

64. Butow, R.A.; Avadhani, N.G. Mitochondrial signaling: The retrograde response. Mol. Cell 2004, 14, 1-15. [CrossRef]

65. Castegna, A.; Iacobazzi, V.; Infantino, V. The mitochondrial side of epigenetics. Physiol. Genom. 2015, 47, 299-307. [CrossRef] [PubMed]

66. Chandel, N.S. Evolution of Mitochondria as Signaling Organelles. Cell Metab. 2015, 22, 204-206. [CrossRef]

67. Frezza, C. Mitochondrial metabolites: Undercover signalling molecules. Interface Focus 2017, 7, 20160100. [CrossRef] [PubMed]

68. Olsen, R.K.; Cornelius, N.; Gregersen, N. Redox signalling and mitochondrial stress responses; lessons from inborn errors of metabolism. J. Inherit. Metab. Dis. 2015, 38, 703-719. [CrossRef]

69. Sullivan, L.B.; Chandel, N.S. Mitochondrial reactive oxygen species and cancer. Cancer Metab. $2014,2,17$. [CrossRef]

70. Hsu, C.C.; Tseng, L.M.; Lee, H.C. Role of mitochondrial dysfunction in cancer progression. Exp. Biol. Med. 2016, 241, 1281-1295. [CrossRef] 
71. Kaelin, W.G., Jr.; McKnight, S.L. Influence of metabolism on epigenetics and disease. Cell 2013, 153, 56-69. [CrossRef]

72. Moro, L.; Arbini, A.A.; Yao, J.L.; di Sant'Agnese, P.A.; Marra, E.; Greco, M. Mitochondrial DNA depletion in prostate epithelial cells promotes anoikis resistance and invasion through activation of PI3K/Akt2. Cell Death Differ. 2009, 16, 571-583. [CrossRef]

73. Koochekpour, S.; Marlowe, T.; Singh, K.K.; Attwood, K.; Chandra, D. Reduced mitochondrial DNA content associates with poor prognosis of prostate cancer in African American men. PLoS ONE 2013, 8, e74688. [CrossRef] [PubMed]

74. Arbini, A.A.; Guerra, F.; Greco, M.; Marra, E.; Gandee, L.; Xiao, G.; Lotan, Y.; Gasparre, G.; Hsieh, J.T.; Moro, L. Mitochondrial DNA depletion sensitizes cancer cells to PARP inhibitors by translational and post-translational repression of BRCA2. Oncogenesis 2013, 2, e82. [CrossRef] [PubMed]

75. Guo, J.; Zheng, L.; Liu, W.; Wang, X.; Wang, Z.; Wang, Z.; French, A.J.; Kang, D.; Chen, L.; Thibodeau, S.N.; et al. Frequent truncating mutation of TFAM induces mitochondrial DNA depletion and apoptotic resistance in microsatellite-unstable colorectal cancer. Cancer Res. 2011, 71, 2978-2987. [CrossRef]

76. Smolkova, K.; Plecita-Hlavata, L.; Bellance, N.; Benard, G.; Rossignol, R.; Jezek, P. Waves of gene regulation suppress and then restore oxidative phosphorylation in cancer cells. Int. J. Biochem. Cell Biol. 2011, 43, 950-968. [CrossRef]

77. Guha, M.; Srinivasan, S.; Ruthel, G.; Kashina, A.K.; Carstens, R.P.; Mendoza, A.; Khanna, C.; Van Winkle, T.; Avadhani, N.G. Mitochondrial retrograde signaling induces epithelial-mesenchymal transition and generates breast cancer stem cells. Oncogene 2014, 33, 5238-5250. [CrossRef]

78. Kalainayakan, S.P.; FitzGerald, K.E.; Konduri, P.C.; Vidal, C.; Zhang, L. Essential roles of mitochondrial and heme function in lung cancer bioenergetics and tumorigenesis. Cell Biosci. 2018, 8, 56. [CrossRef] [PubMed]

79. Berridge, M.V.; Crasso, C.; Neuzil, J. Mitochondrial Genome Transfer to Tumor Cells Breaks The Rules and Establishes a New Precedent in Cancer Biology. Mol. Cell. Oncol. 2018, 5, e1023929. [CrossRef]

80. Tan, A.S.; Baty, J.W.; Dong, L.F.; Bezawork-Geleta, A.; Endaya, B.; Goodwin, J.; Bajzikova, M.; Kovarova, J.; Peterka, M.; Yan, B.; et al. Mitochondrial genome acquisition restores respiratory function and tumorigenic potential of cancer cells without mitochondrial DNA. Cell Metab. 2015, 21, 81-94. [CrossRef]

81. Zhou, Y.; Xu, Z.; Quan, D.; Zhang, F.; Zhang, H.; Xiao, T.; Hou, S.; Qiao, H.; Harismendy, O.; Wang, J.Y.J.; et al. Nuclear respiratory factor 1 promotes spheroid survival and mesenchymal transition in mammary epithelial cells. Oncogene 2018. [CrossRef] [PubMed]

82. Torralba, D.; Baixauli, F.; Sanchez-Madrid, F. Mitochondria Know No Boundaries: Mechanisms and Functions of Intercellular Mitochondrial Transfer. Front. Cell Dev. Biol. 2016, 4, 107. [CrossRef]

83. Berridge, M.V.; Schneider, R.T.; McConnell, M.J. Mitochondrial Transfer from Astrocytes to Neurons following Ischemic Insult: Guilt by Association? Cell Metab. 2016, 24, 376-378. [CrossRef] [PubMed]

84. Berridge, M.V.; Dong, L.; Neuzil, J. Mitochondrial DNA in Tumor Initiation, Progression and Metastasis: Role of Horizontal mtDNA Transfer. Cancer Res. 2015, 75, 3203-3208. [CrossRef] [PubMed]

85. Caicedo, A.; Aponte, P.M.; Cabrera, F.; Hidalgo, C.; Khoury, M. Artificial Mitochondria Transfer: Current Challenges, Advances and Future Applications. Stem Cells Int. 2017, 2017, 7610414. [CrossRef] [PubMed]

86. Mahrouf-Yorgov, M.; Augeul, L.; Da Silva, C.C.; Jourdan, M.; Rigolet, M.; Manin, S.; Ferrera, R.; Ovize, M.; Henry, A.; Guguin, A.; et al. Mesenchymal stem cells sense mitochondria released from damaged cells as danger signals to activate their rescue properties. Cell Death Differ. 2017, 24, 1224-1238. [CrossRef] [PubMed]

87. Caicedo, A.; Fritz, V.; Brondello, J.M.; Ayala, M.; Dennemont, I.; Abdellaoui, N.; de Fraipont, F.; Moisan, A.; Prouteau, C.A.; Boukhaddaoui, H.; et al. MitoCeption as a new tool to assess the effects of mesenchymal stem/stromal cell mitochondria on cancer cell metabolism and function. Sci. Rep. 2015, 5, 9073. [CrossRef] [PubMed]

88. Marlein, C.R.; Zaitseva, L.; Piddock, R.E.; Robinson, S.D.; Edwards, D.R.; Shafat, M.S.; Zhou, Z.; Lawes, M.; Bowles, K.M.; Rushworth, S.A. NADPH oxidase-2 derived superoxide drives mitochondrial transfer from bone marrow stromal cells to leukemic blasts. Blood 2017, 130, 1649-1660. [CrossRef] [PubMed]

89. Moschoi, R.; Imbert, V.; Nebout, M.; Chiche, J.; Mary, D.; Prebet, T.; Saland, E.; Castellano, R.; Pouyet, L.; Collette, Y.; et al. Protective mitochondrial transfer from bone marrow stromal cells to acute myeloid leukemic cells during chemotherapy. Blood 2016, 128, 253-264. [CrossRef] 
90. Pasquier, J.; Guerrouahen, B.S.; Al Thawadi, H.; Ghiabi, P.; Maleki, M.; Abu-Kaoud, N.; Jacob, A.; Mirshahi, M.; Galas, L.; Rafii, S.; et al. Preferential transfer of mitochondria from endothelial to cancer cells through tunneling nanotubes modulates chemoresistance. J. Transl. Med. 2013, 11, 94. [CrossRef]

91. Nowicki, S.; Gottlieb, E. Oncometabolites: Tailoring our genes. FEBS J. 2015, 282, 2796-2805. [CrossRef]

92. Carey, B.W.; Finley, L.W.; Cross, J.R.; Allis, C.D.; Thompson, C.B. Intracellular alpha-ketoglutarate maintains the pluripotency of embryonic stem cells. Nature 2015, 518, 413-416. [CrossRef]

93. Ward, P.S.; Patel, J.; Wise, D.R.; Abdel-Wahab, O.; Bennett, B.D.; Coller, H.A.; Cross, J.R.; Fantin, V.R.; Hedvat, C.V.; Perl, A.E.; et al. The common feature of leukemia-associated IDH1 and IDH2 mutations is a neomorphic enzyme activity converting alpha-ketoglutarate to 2-hydroxyglutarate. Cancer Cell 2010, 17, 225-234. [CrossRef]

94. Xu, W.; Yang, H.; Liu, Y.; Yang, Y.; Wang, P.; Kim, S.H.; Ito, S.; Yang, C.; Wang, P.; Xiao, M.T.; et al. Oncometabolite 2-hydroxyglutarate is a competitive inhibitor of alpha-ketoglutarate-dependent dioxygenases. Cancer Cell. 2011, 19, 17-30. [CrossRef]

95. Latini, A.; da Silva, C.G.; Ferreira, G.C.; Schuck, P.F.; Scussiato, K.; Sarkis, J.J.; Dutra Filho, C.S.; Wyse, A.T.; Wannmacher, C.M.; Wajner, M. Mitochondrial energy metabolism is markedly impaired by D-2-hydroxyglutaric acid in rat tissues. Mol. Genet. Metab. 2005, 86, 188-199. [CrossRef]

96. Reitman, Z.J.; Jin, G.; Karoly, E.D.; Spasojevic, I.; Yang, J.; Kinzler, K.W.; He, Y.; Bigner, D.D.; Vogelstein, B.; Yan, H. Profiling the effects of isocitrate dehydrogenase 1 and 2 mutations on the cellular metabolome. Proc. Natl. Acad. Sci. USA 2011, 108, 3270-3275. [CrossRef]

97. MacKenzie, E.D.; Selak, M.A.; Tennant, D.A.; Payne, L.J.; Crosby, S.; Frederiksen, C.M.; Watson, D.G.; Gottlieb, E. Cell-permeating alpha-ketoglutarate derivatives alleviate pseudohypoxia in succinate dehydrogenase-deficient cells. Mol. Cell. Biol. 2007, 27, 3282-3289. [CrossRef]

98. De, P.; Chatterjee, R. Nucleolar localization of succinic dehydrogenase in human malignant cells with MTT. Experientia 1962, 18, 562. [CrossRef]

99. De, P.; Chatterjee, R. Evidence of nucleolar succinic dehydrogenase activity. Exp. Cell Res. 1962, $27,172-173$. [CrossRef]

100. Killian, J.K.; Kim, S.Y.; Miettinen, M.; Smith, C.; Merino, M.; Tsokos, M.; Quezado, M.; Smith, W.I., Jr.; Jahromi, M.S.; Xekouki, P.; et al. Succinate dehydrogenase mutation underlies global epigenomic divergence in gastrointestinal stromal tumor. Cancer Discov. 2013, 3, 648-657. [CrossRef]

101. Xiao, M.; Yang, H.; Xu, W.; Ma, S.; Lin, H.; Zhu, H.; Liu, L.; Liu, Y.; Yang, C.; Xu, Y.; et al. Inhibition of alpha-KG-dependent histone and DNA demethylases by fumarate and succinate that are accumulated in mutations of FH and SDH tumor suppressors. Genes Dev. 2012, 26, 1326-1338. [CrossRef] [PubMed]

102. Adam, J.; Hatipoglu, E.; O’Flaherty, L.; Ternette, N.; Sahgal, N.; Lockstone, H.; Baban, D.; Nye, E.; Stamp, G.W.; Wolhuter, K.; et al. Renal cyst formation in Fh1-deficient mice is independent of the Hif/Phd pathway: Roles for fumarate in KEAP1 succination and Nrf2 signaling. Cancer Cell 2011, 20, 524-537. [CrossRef] [PubMed]

103. Ooi, A.; Wong, J.C.; Petillo, D.; Roossien, D.; Perrier-Trudova, V.; Whitten, D.; Min, B.W.; Tan, M.H.; Zhang, Z.; Yang, X.J.; et al. An antioxidant response phenotype shared between hereditary and sporadic type 2 papillary renal cell carcinoma. Cancer Cell 2011, 20, 511-523. [CrossRef] [PubMed]

104. DeNicola, G.M.; Karreth, F.A.; Humpton, T.J.; Gopinathan, A.; Wei, C.; Frese, K.; Mangal, D.; Yu, K.H.; Yeo, C.J.; Calhoun, E.S.; et al. Oncogene-induced Nrf2 transcription promotes ROS detoxification and tumorigenesis. Nature 2011, 475, 106-109. [CrossRef] [PubMed]

105. Sullivan, L.B.; Martinez-Garcia, E.; Nguyen, H.; Mullen, A.R.; Dufour, E.; Sudarshan, S.; Licht, J.D.; Deberardinis, R.J.; Chandel, N.S. The proto-oncometabolite fumarate binds glutathione to amplify ROS-dependent signaling. Mol. Cell 2013, 51, 236-248. [CrossRef] [PubMed]

106. Yogev, O.; Yogev, O.; Singer, E.; Shaulian, E.; Goldberg, M.; Fox, T.D.; Pines, O. Fumarase: A mitochondrial metabolic enzyme and a cytosolic/nuclear component of the DNA damage response. PLoS Biol. 2010, 8, e1000328. [CrossRef]

107. Jiang, Y.; Qian, X.; Shen, J.; Wang, Y.; Li, X.; Liu, R.; Xia, Y.; Chen, Q.; Peng, G.; Lin, S.Y.; et al. Local generation of fumarate promotes DNA repair through inhibition of histone H3 demethylation. Nat. Cell Biol. 2015, 17, 1158-1168. [CrossRef]

108. Boukouris, A.E.; Zervopoulos, S.D.; Michelakis, E.D. Metabolic Enzymes Moonlighting in the Nucleus: Metabolic Regulation of Gene Transcription. Trends Biochem. Sci. 2016, 41, 712-730. [CrossRef] 
109. Gao, X.; Wang, H.; Yang, J.J.; Liu, X.; Liu, Z.R. Pyruvate kinase M2 regulates gene transcription by acting as a protein kinase. Mol. Cell 2012, 45, 598-609. [CrossRef]

110. Yang, W.; Xia, Y.; Hawke, D.; Li, X.; Liang, J.; Xing, D.; Aldape, K.; Hunter, T.; Alfred Yung, W.K.; Lu, Z. PKM2 phosphorylates histone $\mathrm{H} 3$ and promotes gene transcription and tumorigenesis. Cell 2012, 150, 685-696. [CrossRef]

111. Matsuda, S.; Adachi, J.; Ihara, M.; Tanuma, N.; Shima, H.; Kakizuka, A.; Ikura, M.; Ikura, T.; Matsuda, T. Nuclear pyruvate kinase M2 complex serves as a transcriptional coactivator of arylhydrocarbon receptor. Nucleic Acids Res. 2016, 44, 636-647. [CrossRef] [PubMed]

112. Sutendra, G.; Kinnaird, A.; Dromparis, P.; Paulin, R.; Stenson, T.H.; Haromy, A.; Hashimoto, K.; Zhang, N.; Flaim, E.; Michelakis, E.D. A nuclear pyruvate dehydrogenase complex is important for the generation of acetyl-CoA and histone acetylation. Cell 2014, 158, 84-97. [CrossRef] [PubMed]

113. Luo, W.; Hu, H.; Chang, R.; Zhong, J.; Knabel, M.; O’Meally, R.; Cole, R.N.; Pandey, A.; Semenza, G.L. Pyruvate kinase M2 is a PHD3-stimulated coactivator for hypoxia-inducible factor 1. Cell 2011, 145, 732-744. [CrossRef] [PubMed]

114. Wang, H.J.; Hsieh, Y.J.; Cheng, W.C.; Lin, C.P.; Lin, Y.S.; Yang, S.F.; Chen, C.C.; Izumiya, Y.; Yu, J.S.; Kung, H.J.; et al. JMJD5 regulates PKM2 nuclear translocation and reprograms HIF-1alpha-mediated glucose metabolism. Proc. Natl. Acad. Sci. USA 2014, 111, 279-284. [CrossRef]

115. Picard, M.; Wallace, D.C.; Burelle, Y. The rise of mitochondria in medicine. Mitochondrion 2016, 30, $105-116$. [CrossRef]

116. Picard, M.; Zhang, J.; Hancock, S.; Derbeneva, O.; Golhar, R.; Golik, P.; O’Hearn, S.; Levy, S.; Potluri, P.; Lvova, M.; et al. Progressive increase in mtDNA 3243A $>$ G heteroplasmy causes abrupt transcriptional reprogramming. Proc. Natl. Acad. Sci. USA 2014, 111, E4033-E4042. [CrossRef]

117. He, Y.; Gao, M.; Cao, Y.; Tang, H.; Liu, S.; Tao, Y. Nuclear localization of metabolic enzymes in immunity and metastasis. Biochim. Biophys. Acta Rev. Cancer 2017, 1868, 359-371. [CrossRef] [PubMed]

118. Huang, W.C.; Chen, C.C. Akt phosphorylation of p300 at Ser-1834 is essential for its histone acetyltransferase and transcriptional activity. Mol. Cell. Biol. 2005, 25, 6592-6602. [CrossRef]

119. Lv, L.; Xu, Y.P.; Zhao, D.; Li, F.L.; Wang, W.; Sasaki, N.; Jiang, Y.; Zhou, X.; Li, T.T.; Guan, K.L.; et al. Mitogenic and oncogenic stimulation of K433 acetylation promotes PKM2 protein kinase activity and nuclear localization. Mol. Cell 2013, 52, 340-352. [CrossRef]

120. Faiola, F.; Liu, X.; Lo, S.; Pan, S.; Zhang, K.; Lymar, E.; Farina, A.; Martinez, E. Dual regulation of c-Myc by p300 via acetylation-dependent control of Myc protein turnover and coactivation of Myc-induced transcription. Mol. Cell. Biol. 2005, 25, 10220-10234. [CrossRef]

121. Neary, C.L.; Pastorino, J.G. Nucleocytoplasmic shuttling of hexokinase II in a cancer cell. Biochem. Biophys. Res. Commun. 2010, 394, 1075-1081. [CrossRef]

122. Neary, C.L.; Pastorino, J.G. Akt inhibition promotes hexokinase 2 redistribution and glucose uptake in cancer cells. J. Cell. Physiol. 2013, 228, 1943-1948. [CrossRef]

123. Vega, M.; Riera, A.; Fernandez-Cid, A.; Herrero, P.; Moreno, F. Hexokinase 2 Is an Intracellular Glucose Sensor of Yeast Cells That Maintains the Structure and Activity of Mig1 Protein Repressor Complex. J. Biol. Chem. 2016, 291, 7267-7285. [CrossRef]

124. Zhong, X.H.; Howard, B.D. Phosphotyrosine-containing lactate dehydrogenase is restricted to the nuclei of PC12 pheochromocytoma cells. Mol. Cell. Biol. 1990, 10, 770-776. [CrossRef]

125. Cooper, J.A.; Reiss, N.A.; Schwartz, R.J.; Hunter, T. Three glycolytic enzymes are phosphorylated at tyrosine in cells transformed by Rous sarcoma virus. Nature 1983, 302, 218-223. [CrossRef]

126. Castonguay, Z.; Auger, C.; Thomas, S.C.; Chahma, M.; Appanna, V.D. Nuclear lactate dehydrogenase modulates histone modification in human hepatocytes. Biochem. Biophys. Res. Commun. 2014, 454, 172-177. [CrossRef]

127. Popanda, O.; Fox, G.; Thielmann, H.W. Modulation of DNA polymerases alpha, delta and epsilon by lactate dehydrogenase and 3-phosphoglycerate kinase. Biochim. Biophys. Acta 1998, 1397, 102-117. [CrossRef]

128. Liu, Y.; Guo, J.Z.; Liu, Y.; Wang, K.; Ding, W.; Wang, H.; Liu, X.; Zhou, S.; Lu, X.C.; Yang, H.B.; et al. Nuclear lactate dehydrogenase A senses ROS to produce alpha-hydroxybutyrate for HPV-induced cervical tumor growth. Nat. Commun. 2018, 9, 4429. [CrossRef]

129. Chang, M.; Hamilton, J.A.; Scholz, G.M.; Elsegood, C.L. Glycolytic control of adjuvant-induced macrophage survival: Role of PI3K, MEK1/2 and Bcl-2. J. Leuk. Biol. 2009, 85, 947-956. [CrossRef] 
130. Chang, C.H.; Curtis, J.D.; Maggi, L.B., Jr.; Faubert, B.; Villarino, A.V.; O'Sullivan, D.; Huang, S.C.; van der Windt, G.J.; Blagih, J.; Qiu, J.; et al. Posttranscriptional control of T cell effector function by aerobic glycolysis. Cell 2013, 153, 1239-1251. [CrossRef]

131. Biswas, S.K. Metabolic Reprogramming of Immune Cells in Cancer Progression. Immunity 2015, 43, 435-449. [CrossRef] [PubMed]

132. Corrado, M.; Scorrano, L.; Campello, S. Changing perspective on oncometabolites: From metabolic signature of cancer to tumorigenic and immunosuppressive agents. Oncotarget 2016, 7, 46692-46706. [CrossRef] [PubMed]

133. Malinarich, F.; Duan, K.; Hamid, R.A.; Bijin, A.; Lin, W.X.; Poidinger, M.; Fairhurst, A.M.; Connolly, J.E. High mitochondrial respiration and glycolytic capacity represent a metabolic phenotype of human tolerogenic dendritic cells. J. Immunol. 2015, 194, 5174-5186. [CrossRef] [PubMed]

134. Van den Bossche, J.; Baardman, J.; Otto, N.A.; van der Velden, S.; Neele, A.E.; van den Berg, S.M.; Luque-Martin, R.; Chen, H.J.; Boshuizen, M.C.; Ahmed, M.; et al. Mitochondrial Dysfunction Prevents Repolarization of Inflammatory Macrophages. Cell Rep. 2016, 17, 684-696. [CrossRef] [PubMed]

135. Wang, F.; Zhang, S.; Vuckovic, I.; Jeon, R.; Lerman, A.; Folmes, C.D.; Dzeja, P.P.; Herrmann, J. Glycolytic Stimulation Is Not a Requirement for M2 Macrophage Differentiation. Cell Metab. 2018, 28, 463-475.e4. [CrossRef]

136. Vats, D.; Mukundan, L.; Odegaard, J.I.; Zhang, L.; Smith, K.L.; Morel, C.R.; Wagner, R.A.; Greaves, D.R.; Murray, P.J.; Chawla, A. Oxidative metabolism and PGC-1beta attenuate macrophage-mediated inflammation. Cell Metab. 2006, 4, 13-24. [CrossRef] [PubMed]

137. Huang, S.C.; Everts, B.; Ivanova, Y.; O’Sullivan, D.; Nascimento, M.; Smith, A.M.; Beatty, W.; Love-Gregory, L.; Lam, W.Y.; O'Neill, C.M.; et al. Cell-intrinsic lysosomal lipolysis is essential for alternative activation of macrophages. Nat. Immunol. 2014, 15, 846-855. [CrossRef]

138. Assmann, N.; Finlay, D.K. Metabolic regulation of immune responses: Therapeutic opportunities. J. Clin. Investig. 2016, 126, 2031-2039. [CrossRef] [PubMed]

139. Kelly, B.; Tannahill, G.M.; Murphy, M.P.; O'Neill, L.A. Metformin Inhibits the Production of Reactive Oxygen Species from NADH:Ubiquinone Oxidoreductase to Limit Induction of Interleukin-1 $($ IL-1 $\beta$ ) and Boosts Interleukin-10 (IL-10) in Lipopolysaccharide (LPS)-activated Macrophages. J. Biol. Chem. 2015, 290, 20348-20359. [CrossRef] [PubMed]

140. Mounier, R.; Theret, M.; Arnold, L.; Cuvellier, S.; Bultot, L.; Goransson, O.; Sanz, N.; Ferry, A.; Sakamoto, K.; Foretz, M.; et al. AMPKalpha1 regulates macrophage skewing at the time of resolution of inflammation during skeletal muscle regeneration. Cell Metab. 2013, 18, 251-264. [CrossRef] [PubMed]

141. Mills, E.L.; O'Neill, L.A. Reprogramming mitochondrial metabolism in macrophages as an anti-inflammatory signal. Eur. J. Immunol. 2016, 46, 13-21. [CrossRef]

142. De Rosa, V.; Galgani, M.; Porcellini, A.; Colamatteo, A.; Santopaolo, M.; Zuchegna, C.; Romano, A.; De Simone, S.; Procaccini, C.; La Rocca, C.; et al. Glycolysis controls the induction of human regulatory T cells by modulating the expression of FOXP3 exon 2 splicing variants. Nat. Immunol. 2015, 16, 1174-1184. [CrossRef]

143. Gerriets, V.A.; Kishton, R.J.; Johnson, M.O.; Cohen, S.; Siska, P.J.; Nichols, A.G.; Warmoes, M.O.; de Cubas, A.A.; MacIver, N.J.; Locasale, J.W.; et al. Foxp3 and Toll-like receptor signaling balance Treg cell anabolic metabolism for suppression. Nat. Immunol. 2016, 17, 1459-1466. [CrossRef]

144. Andrejeva, G.; Rathmell, J.C. Similarities and Distinctions of Cancer and Immune Metabolism in Inflammation and Tumors. Cell Metab. 2017, 26, 49-70. [CrossRef]

145. Sotgia, F.; Martinez-Outschoorn, U.E.; Lisanti, M.P. Cancer metabolism: New validated targets for drug discovery. Oncotarget 2013, 4, 1309-1316. [CrossRef]

146. Pavlides, S.; Whitaker-Menezes, D.; Castello-Cros, R.; Flomenberg, N.; Witkiewicz, A.K.; Frank, P.G.; Casimiro, M.C.; Wang, C.; Fortina, P.; Addya, S.; et al. The reverse Warburg effect: Aerobic glycolysis in cancer associated fibroblasts and the tumor stroma. Cell Cycle 2009, 8, 3984-4001. [CrossRef]

147. Tan, H.Y.; Wang, N.; Li, S.; Hong, M.; Wang, X.; Feng, Y. The Reactive Oxygen Species in Macrophage Polarization: Reflecting Its Dual Role in Progression and Treatment of Human Diseases. Oxid. Med. Cell. Longev. 2016, 2016, 2795090. [CrossRef]

148. Zhang, Y.; Choksi, S.; Chen, K.; Pobezinskaya, Y.; Linnoila, I.; Liu, Z.G. ROS play a critical role in the differentiation of alternatively activated macrophages and the occurrence of tumor-associated macrophages. Cell Res. 2013, 23, 898-914. [CrossRef] 
149. Srinivasan, S.; Koenigstein, A.; Joseph, J.; Sun, L.; Kalyanaraman, B.; Zaidi, M.; Avadhani, N.G. Role of mitochondrial reactive oxygen species in osteoclast differentiation. Ann. N. Y. Acad. Sci. 2010, 1192, $245-252$. [CrossRef]

150. Formentini, L.; Santacatterina, F.; Nunez de Arenas, C.; Stamatakis, K.; Lopez-Martinez, D.; Logan, A.; Fresno, M.; Smits, R.; Murphy, M.P.; Cuezva, J.M. Mitochondrial ROS Production Protects the Intestine from Inflammation through Functional M2 Macrophage Polarization. Cell Rep. 2017, 19, 1202-1213. [CrossRef]

151. Chang, C.H.; Qiu, J.; O’Sullivan, D.; Buck, M.D.; Noguchi, T.; Curtis, J.D.; Chen, Q.; Gindin, M.; Gubin, M.M.; van der Windt, G.J.; et al. Metabolic Competition in the Tumor Microenvironment Is a Driver of Cancer Progression. Cell 2015, 162, 1229-1241. [CrossRef] [PubMed]

152. Kim, J.; Bae, J.S. Metabolic regulation of macrophages in tumor microenvironment. Curr. Opin. Hematol. 2017. [CrossRef] [PubMed]

153. Chawla, A. Control of macrophage activation and function by PPARs. Circ. Res. 2010, 106, 1559-1569. [CrossRef] [PubMed]

154. Vellinga, T.T.; Borovski, T.; de Boer, V.C.; Fatrai, S.; van Schelven, S.; Trumpi, K.; Verheem, A.; Snoeren, N.; Emmink, B.L.; Koster, J.; et al. SIRT1/PGC1alpha-Dependent Increase in Oxidative Phosphorylation Supports Chemotherapy Resistance of Colon Cancer. Clin. Cancer Res. 2015, 21, 2870-2879. [CrossRef] [PubMed]

155. Pelicano, H.; Xu, R.H.; Du, M.; Feng, L.; Sasaki, R.; Carew, J.S.; Hu, Y.; Ramdas, L.; Hu, L.; Keating, M.J.; et al. Mitochondrial respiration defects in cancer cells cause activation of Akt survival pathway through a redox-mediated mechanism. J. Cell Biol. 2006, 175, 913-923. [CrossRef] [PubMed]

156. Sahin, E.; Haubenwallner, S.; Kuttke, M.; Kollmann, I.; Halfmann, A.; Dohnal, A.M.; Chen, L.; Cheng, P.; Hoesel, B.; Einwallner, E.; et al. Macrophage PTEN regulates expression and secretion of arginase I modulating innate and adaptive immune responses. J. Immunol. 2014, 193, 1717-1727. [CrossRef]

157. Kral, J.B.; Kuttke, M.; Schrottmaier, W.C.; Birnecker, B.; Warszawska, J.; Wernig, C.; Paar, H.; Salzmann, M.; Sahin, E.; Brunner, J.S.; et al. Sustained PI3K Activation exacerbates BLM-induced Lung Fibrosis via activation of pro-inflammatory and pro-fibrotic pathways. Sci. Rep. 2016, 6, 23034. [CrossRef] [PubMed]

158. Vergadi, E.; Ieronymaki, E.; Lyroni, K.; Vaporidi, K.; Tsatsanis, C. Akt Signaling Pathway in Macrophage Activation and M1/M2 Polarization. J. Immunol. 2017, 198, 1006-1014. [CrossRef] [PubMed]

159. Chowdhury, A.R.; Long, A.; Fuchs, S.Y.; Rustgi, A.; Avadhani, N.G. Mitochondrial stress-induced p53 attenuates HIF-1alpha activity by physical association and enhanced ubiquitination. Oncogene 2017, 36, 397-409. [CrossRef] [PubMed]

160. Velez, J.M.; Miriyala, S.; Nithipongvanitch, R.; Noel, T.; Plabplueng, C.D.; Oberley, T.; Jungsuwadee, P.; Van Remmen, H.; Vore, M.; St Clair, D.K. p53 Regulates oxidative stress-mediated retrograde signaling: A novel mechanism for chemotherapy-induced cardiac injury. PLoS ONE 2011, 6, e18005. [CrossRef] [PubMed]

161. Itahana, Y.; Itahana, K. Emerging Roles of p53 Family Members in Glucose Metabolism. Int. J. Mol. Sci. 2018, 19, 776. [CrossRef] [PubMed]

162. Puzio-Kuter, A.M. The Role of p53 in Metabolic Regulation. Genes Cancer 2011, 2, 385-391. [CrossRef] [PubMed]

163. Mukhopadhyay, S.; Antalis, T.M.; Nguyen, K.P.; Hoofnagle, M.H.; Sarkar, R. Myeloid p53 regulates macrophage polarization and venous thrombus resolution by inflammatory vascular remodeling in mice. Blood 2017, 129, 3245-3255. [CrossRef] [PubMed]

164. He, X.Y.; Xiang, C.; Zhang, C.X.; Xie, Y.Y.; Chen, L.; Zhang, G.X.; Lu, Y.; Liu, G. p53 in the Myeloid Lineage Modulates an Inflammatory Microenvironment Limiting Initiation and Invasion of Intestinal Tumors. Cell Rep. 2015, 13, 888-897. [CrossRef]

165. Li, L.; Ng, D.S.; Mah, W.C.; Almeida, F.F.; Rahmat, S.A.; Rao, V.K.; Leow, S.C.; Laudisi, F.; Peh, M.T.; Goh, A.M.; et al. A unique role for p53 in the regulation of M2 macrophage polarization. Cell Death Differ. 2015, 22, 1081-1093. [CrossRef]

166. Lowe, J.M.; Menendez, D.; Bushel, P.R.; Shatz, M.; Kirk, E.L.; Troester, M.A.; Garantziotis, S.; Fessler, M.B.; Resnick, M.A. p53 and NF-kB coregulate proinflammatory gene responses in human macrophages. Cancer Res. 2014, 74, 2182-2192. [CrossRef]

(C) 2019 by the authors. Licensee MDPI, Basel, Switzerland. This article is an open access article distributed under the terms and conditions of the Creative Commons Attribution (CC BY) license (http://creativecommons.org/licenses/by/4.0/). 